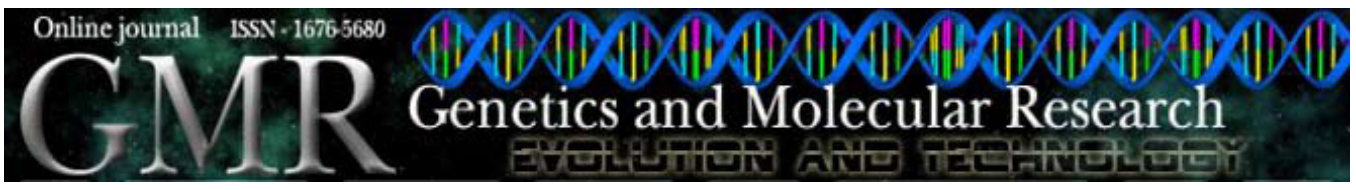

\title{
Karyoevolution of the toadfish Thalassophryne nattereri (Batrachoidiformes: Batrachoididae)
}

\author{
G.W.W.F. Costa and W.F. Molina \\ Departamento de Biologia Celular e Genética, Centro de Biociências, \\ Universidade Federal do Rio Grande do Norte, Natal, RN, Brasil \\ Corresponding author: W.F. Molina \\ E-mail: molinawf@yahoo.com.br
}

Genet. Mol. Res. 8 (3): 1099-1106 (2009)

Received May 26, 2009

Accepted July 8, 2009

Published September 8, 2009

\begin{abstract}
The Batrachoididae includes some venomous brackish and marine fish found in the Atlantic, Indian and Pacific oceans. This family is composed of 69 species, distributed among 19 genera. Species of the genus Thalassophryne have been reported along the coast of Rio Grande do Norte (Brazil); T. nattereri has been responsible for a large number of human injuries. Little is known about the cytogenetic features of this family. We made a karyotypic characterization of T. nattereri collected from the estuary of the Apodi/Mossoró River, using conventional Giemsa staining, C-banding and silver nitrate-nucleolar organizer region technique. There was a modal diploid value of $2 n=46$ chromosomes $(8 m+8 s m+24 s t+6 a$; fundamental number $=86)$. Single ribosomal sites were detected in the terminal region on short arms of a subtelocentric pair (19th). Heterochromatin segments were preferentially located over centromeric regions in some chromosome pairs. Pericentric inversions and Robertsonian rearrangements seem to have played a major role in karyotype evolution within this genus of toadfish.
\end{abstract}

Key words: Fish cytogenetics; Pericentric inversion; Toadfish; Thalassophryne; Venomous fish 


\section{INTRODUCTION}

Venomous fish are found in several fish orders such as Siluriformes, Batrachoidiformes (Thalassophryninae), Scorpaeniformes (Scorpaenoidei), and Perciformes (Acanthuroidei, Blennioidei, Percoidei, Trachinoidei) (Stiassny et al., 2004; Nelson, 2006). Batrachoidiformes is the only order in this group regarded as monophyletic (Chen et al., 2003; Miya et al., 2003; Smith and Wheeler, 2004, 2006).

The members of the family Batrachoididae (19 genera and 69 species) are coastal ambush predators feeding on mollusks, crustaceans and fish, and are widespread throughout the Atlantic, Indian and Pacific oceans (Chagas et al., 2004). Several human injuries along the Brazilian shore are thought to be caused by contact with species from this family. All toadfishes possess sharp spines on fins and on the opercle. In members of the subfamily Thalassophryninae, these spines are hollow and connect to venom glands capable of perforating the skin and delivering a painful wound when handled or accidently stepped on by bathers (Collette, 1978; Cervigón, 1991; Lopes-Ferreira et al., 2000; Nelson, 2006). Accidents related to the species Thalassophryne nattereri have been common along the Brazilian coast, particularly on the North and Northeast coast, representing a public health issue (Haddad Jr. et al., 2003; Facó et al., 2005).

Most information about toadfishes along the South American Atlantic coast refers to taxonomy and systematics, including recent description of new genera (Greenfield, 2006), and few reports about biological aspects of some species (Randall, 1983; Menezes and Buckup, 2003; Chagas et al., 2004).

The genus Thalassophryne comprises six species recognized by a scaleless body with a single lateral line, eyes set high on large heads, wide mouth, pelvic fins under the gills, and presence of venomous spines on dorsal fins and opercles (Collette, 1978; Cervigón, 1991).

Chromosomal analyses have been successfully used in the identification of cryptic species (Bertollo et al., 1978, 2004), or else in providing additional data for phylogenetic studies (Brum and Galleti Jr., 1997). Nonetheless, despite their ecological and evolutionary importance, the cytogenetic features of Batrachoididae remain overlooked, with available reports on just a few Neotropical species.

In order to extend the cytogenetic data in this peculiar fish group, currently referred to as an experimental model in biomedicine (Lopes-Ferreira et al., 2000, 2004; Smith and Wheeler, 2006), we characterized the karyotype of Thalassophryne nattereri by Giemsa staining, analysis of heterochromatin distribution and position and number of major ribosomal sites.

\section{MATERIAL AND METHODS}

Ten specimens of $T$. nattereri (four males, four females and two juveniles) were

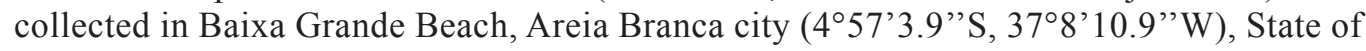
Rio Grande do Norte, Brazil (Figure 1). Mitotic stimulation was then carried out in the collected individuals by intraperitoneal injection of a glucose-yeast solution $(1 \mathrm{~mL} / 100 \mathrm{~g}$ body weight), and the animals were kept in aerated aquaria for 24 to $48 \mathrm{~h}$ (Lee and Elder, 1980). Afterwards, the animals were anesthetized with clove oil and sacrificed for removal of the anterior kidney. 


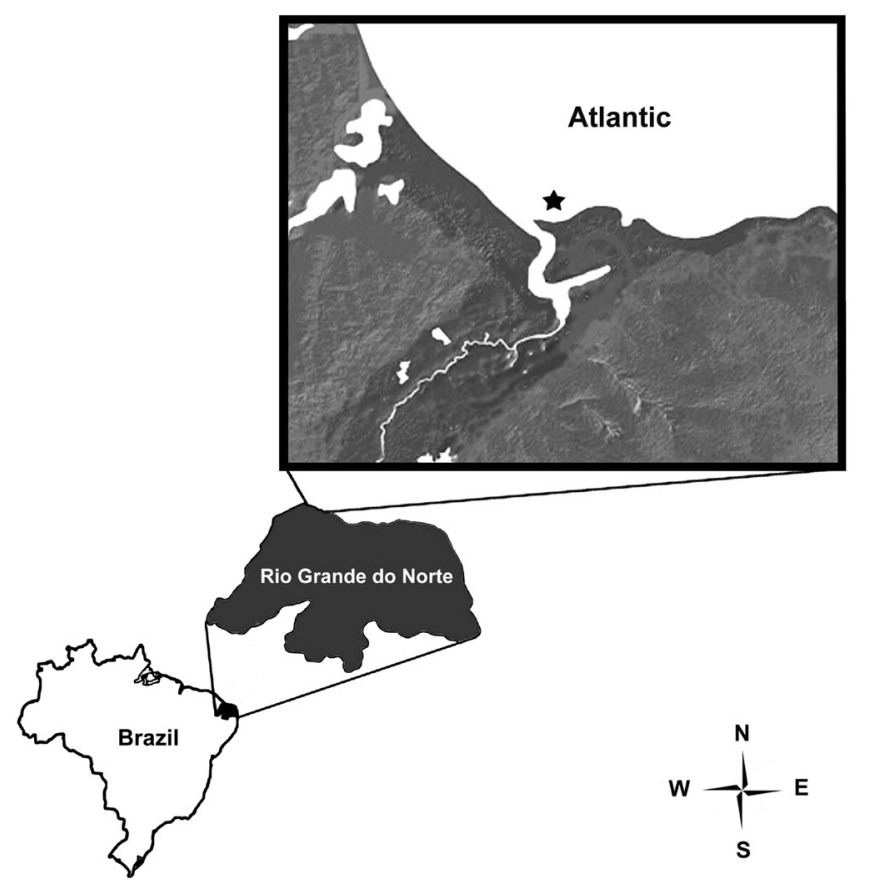

Figure 1. Map of collection site of Thalassophryne nattereri on the shore of Areia Branca (4 $57^{\prime} 3.9^{\prime \prime}$ S; 37 8' 10.9" W), Rio Grande do Norte, Brazil.

Sex identification was performed by macroscopic examination of gonads. Mitotic chromosomes were obtained from kidney cells according to Gold et al. (1990). The nucleolar organizer regions (NORs) and the heterochromatic regions were detected respectively by silver nitrate staining (Ag-NOR) according to Howell and Black (1980) and C-banding (Sumner, 1972). Based on the centromere position, the chromosomes were classified as metacentric (m), submetacentric (sm), subtelocentric (st), and acrocentric (a) (Levan et al., 1964). The fundamental number (FN) was obtained taking into account acrocentric chromosomes as one-armed elements. In order to provide a reliable comparison, the FN in other members of this family was calculated using the same criterion. An ideogram showing the chromosomal morphology and size, distribution of heterochromatin and location of NORs was constructed using the EasyIdio version 3.0 software (Diniz and Xavier, 2006), based on the measurements of chromosome pairs in digitized images in the ImageTool version 3.0 software.

\section{RESULTS}

The cytogenetic analyses of $T$. nattereri showed a diploid value of $2 \mathrm{n}=46$ chromosomes with a karyotype formula consisting of $8 \mathrm{~m}+8 \mathrm{sm}+24 \mathrm{st}+6 \mathrm{a}, \mathrm{FN}=86$ (Figure 2A). No sex-related chromosomal heteromorphism was detected. The species show an asymmetric karyotype, with a first metacentric pair nearly four times larger than the smallest chromosomal pair (8th pair, sm). Detailed measures of chromosomes are presented in Table 1. 


\begin{tabular}{|c|c|c|c|c|c|c|c|}
\hline Pair & Chromosomal size & Long $\operatorname{arm}(\mathrm{q})$ & Short arm (p) & $\mathrm{q} / \mathrm{p}$ ratio & Type & RL (\%) & $\mathrm{CI}$ \\
\hline 1 & 5.55 & 3.35 & 2.20 & 1.52 & $\mathrm{~m}$ & 7.49 & 39.64 \\
\hline 2 & 3.59 & 2.09 & 1.50 & 1.39 & $\mathrm{~m}$ & 4.84 & 41.78 \\
\hline 3 & 3.19 & 1.73 & 1.46 & 1.18 & $\mathrm{~m}$ & 4.30 & 45.77 \\
\hline 4 & 1.67 & 1.02 & 0.65 & 1.57 & $\mathrm{~m}$ & 2.25 & 38.92 \\
\hline 5 & 3.06 & 2.09 & 0.97 & 2.15 & $\mathrm{sm}$ & 4.13 & 31.70 \\
\hline 6 & 2.63 & 1.85 & 0.78 & 2.37 & $\mathrm{sm}$ & 3.55 & 29.66 \\
\hline 7 & 2.44 & 1.73 & 0.71 & 2.44 & $\mathrm{sm}$ & 3.29 & 29.10 \\
\hline 8 & 1.27 & 0.92 & 0.35 & 2.63 & $\mathrm{sm}$ & 1.71 & 27.56 \\
\hline 9 & 4.35 & 3.75 & 0.60 & 6.25 & st & 5.87 & 13.79 \\
\hline 10 & 4.09 & 3.51 & 0.58 & 6.05 & st & 5.52 & 14.18 \\
\hline 11 & 3.93 & 3.40 & 0.53 & 6.42 & st & 5.30 & 13.49 \\
\hline 12 & 3.79 & 3.28 & 0.51 & 6.43 & st & 5.11 & 13.46 \\
\hline 13 & 3.68 & 3.13 & 0.55 & 5.69 & st & 4.96 & 14.95 \\
\hline 14 & 3.54 & 3.08 & 0.46 & 6.70 & st & 4.78 & 12.99 \\
\hline 15 & 3.34 & 2.86 & 0.48 & 5.96 & st & 4.51 & 14.37 \\
\hline 16 & 3.07 & 2.66 & 0.41 & 6.49 & st & 4.14 & 13.36 \\
\hline 17 & 2.86 & 2.49 & 0.37 & 6.73 & st & 3.86 & 12.94 \\
\hline 18 & 2.70 & 2.35 & 0.35 & 6.71 & st & 3.64 & 12.96 \\
\hline 19 & 2.46 & 2.09 & 0.37 & 5.65 & st & 3.32 & 15.04 \\
\hline 20 & 2.27 & 1.90 & 0.37 & 5.14 & st & 3.06 & 16.30 \\
\hline 21 & 4.67 & 4.25 & 0.42 & 10.12 & a & 6.30 & 8.99 \\
\hline 22 & 4.29 & 3.90 & 0.39 & 10.00 & $\mathrm{a}$ & 5.79 & 9.09 \\
\hline 23 & 1.69 & 1.50 & 0.19 & 7.89 & $\mathrm{a}$ & 2.28 & 11.24 \\
\hline
\end{tabular}

$\mathrm{RL}=$ relative length; $\mathrm{CI}=$ centromeric index; $\mathrm{m}=$ metacentric; $\mathrm{sm}=$ submetacentric $\mathrm{st}=$ subtelocentric; $\mathrm{a}=$ acrocentric .

The ribosomal sites are located at the terminal position on short arms of pair 19 (Figure $2 \mathrm{~A}$, inset). Conspicuous heterochromatic blocks are distributed at centromeric regions in most chromosome pairs (Figure 2B,C).

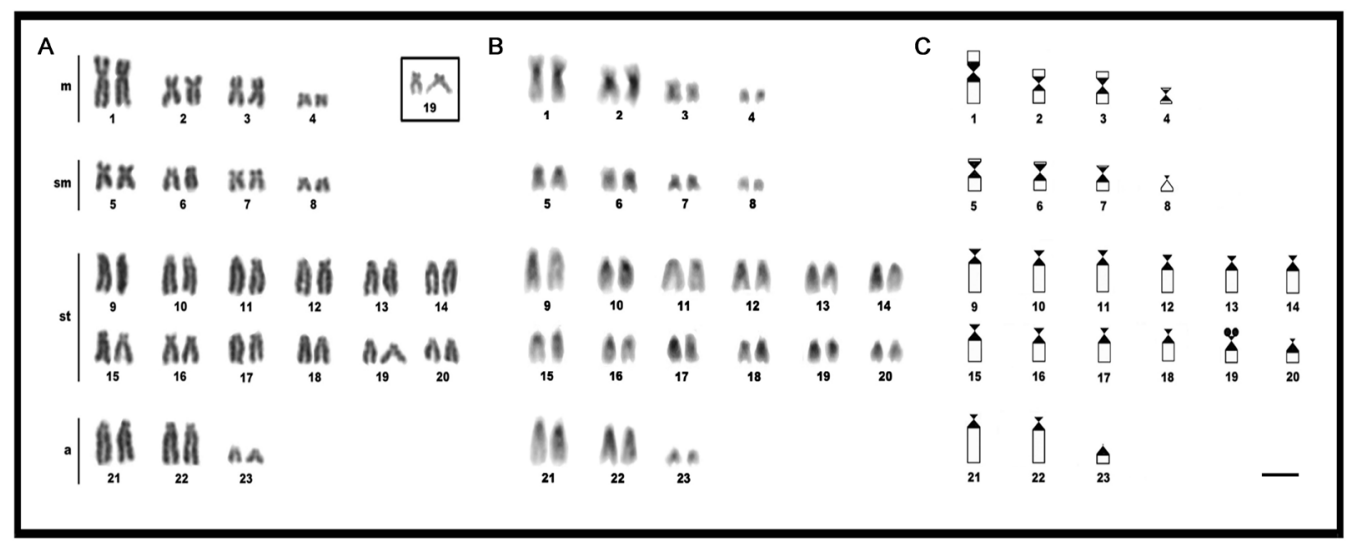

Figure 2. Karyotype of Thalassophryne nattereri (A,B). A. Conventional Giemsa staining with the nucleolar organizer region (NOR)-bearing pair (19) after silver nitrate (Ag) staining (inset). B. C-banding pattern. C. Ideogram comprising the chromosomal morphology, heterochromatin distribution and Ag-NOR location in the karyotype. $\mathrm{m}=$ metacentric; $\mathrm{sm}=$ submetacentric; $\mathrm{st}=$ subtelocentric; $\mathrm{a}=$ acrocentric. $\mathrm{Bar}=5 \mu \mathrm{m}$. 


\section{DISCUSSION}

The main difference in the karyotypic macrostructure between T. nattereri and T. maculosa from the Venezuela coast (Nirchio et al., 2004a) seems to involve the occurrence of pericentric inversions leading to distinct karyotypic formulae. Besides the oceanic distance between the collection sites, both species are isolated by the Amazon River outflow, originating 6 to 10 million years ago (Floeter et al., 2007), and recognized as an important biogeographic barrier for several taxa, causing the disruption between Caribbean and Brazilian fauna (Rocha et al., 2002).

Regarding cytotaxonomic features, $T$. nattereri is characterized by showing the highest FN reported so far in Batrachoididae (Table 2).

Table 2. Cytogenetic data for species of the family Batrachoididae.

\begin{tabular}{llclc}
\hline Species & $2 \mathrm{n}$ & Karyotype formula & FN & References \\
\hline Amphychthys cryptocentrus & 46 & $4 \mathrm{~m}+2 \mathrm{sm}+40 \mathrm{a}$ & 52 & Nirchio et al., 2002 \\
Batrachoides manglae & 46 & $6 \mathrm{~m}+6 \mathrm{sm}+34 \mathrm{a}$ & 58 & Nirchio et al., 2002 \\
Batrachoides pacifici & 46 & $6 \mathrm{~m}+6 \mathrm{sm}+34 \mathrm{a}$ & 58 & Nirchio et al., 2002 \\
Halobatrachus didactylus & 46 & $8 \mathrm{~m}+18 \mathrm{sm}+4 \mathrm{st}+16 \mathrm{a}$ & 76 & Merlo et al., 2007 \\
Halobatrachus didactylus & 46 & $8 \mathrm{~m}+12 \mathrm{sm}+26 \mathrm{a}$ & 66 & Palazón et al., 2003 \\
Porichthys porosissimus & 44 & $14 \mathrm{~m} / \mathrm{sm}+30 \mathrm{st} / \mathrm{a}$ & Brum et al., 2001 \\
Porichthys plectrodon & 44 & $8 \mathrm{~m}+10 \mathrm{sm}+6 \mathrm{st}+20 \mathrm{a}$ & $68^{*}$ & Nirchio et al., 2004b \\
Thalassophryne maculosa & 46 & $8 \mathrm{~m}+6 \mathrm{sm}+32 \mathrm{a}$ & Nirchio et al., 2002 \\
Thalassophryne maculosa & 46 & $8 \mathrm{~m}+6 \mathrm{sm}+20 \mathrm{st}+8 \mathrm{a}$ & $84^{*}$ & Nirchio et al., 2004a \\
Thalassophryne nattereri & 46 & 86 & Present study \\
\hline
\end{tabular}

*Number of chromosome arms considering subtelocentric chromosomes as bi-armed elements. $\mathrm{m}=$ metacentric; $\mathrm{sm}=$ submetacentric; $\mathrm{st}=$ subtelocentric; $\mathrm{a}=$ acrocentric; $\mathrm{FN}=$ fundamental nuber.

The available karyotypic data in representatives of four genera within Batrachoididae reveal a common diploid number of $2 \mathrm{n}=46$ chromosomes, thereby suggesting that it should represent a basal condition for the family. The only exception is reported in the genus Porichthys, with a diploid value of $2 \mathrm{n}=44$ in both species analyzed (Table 2 ).

Assuming that the chromosomes of modern teleosteans evolved from an ancestor karyotype of 48 acrocentric chromosomes (Brum, 1996; Brum and Galetti Jr., 1997), the Batrachoididae species might have undergone a reduction in the chromosomal number from $2 n=48$ to $2 n=46$ during their karyotypic evolution. A Robertsonian event involving two chromosome pairs putatively occurred in the base of the phyletic diversification of this family and would be regarded as a basal condition observed in Amphychthys, Batrachoides, Halobatrachus, and Thalassophryne. Two centric fusions among four chromosome pairs would be required for the establishment of $2 \mathrm{n}=44$ karyotypes, thereby representing an apomorphic trait, exclusively found in the genus Porichthys.

Contradictory karyotypic formulae have been reported in a single species of Batrachoididae (Palazón et al., 2003; Merlo et al., 2007), and some of them are quite discrepant (Nirchio et al., 2002, 2004a). However, the relatively large number of subtelocentric chromosomes in the karyotypes coupled with an imprecise differentiation between subtelocentric and acrocentric chromosomes should account for most of the differences in the number of chromosome arms observed within this family. Nonetheless, compared to the restricted $2 \mathrm{n}$ range, a remarkable variation in chromosome arms $(\mathrm{FN}=52-86)$ can be observed in members of this family, reflecting a key role of pericentric inversions in the karyotype modeling of current species. 
Differences in the fundamental number among closely related species corroborate the importance of pericentric inversions as the main mechanism of karyotypic evolution in several modern fish orders (Molina, 2006). Among toadfishes, the pericentric inversions have occurred in addition to centric fusions; the latter involving a few chromosomes in a putative temporary and ancestral condition.

Chromosomal measurements in T. nattereri demonstrated that the largest chromosome pair shows an average size of $5.5 \mu \mathrm{m}$, or $7.49 \%$ of the total karyotype length, while, in Porichthys plectrodon (Nirchio et al., 2004b), the first pair represents a relatively larger portion of the total karyotype length $(13.5 \%)$ but the same absolute size $(5.48 \mu \mathrm{m})$. Some morphological and size features of the first chromosome pair seem to indicate a homeologous condition for the first metacentric pair within this family, although the presence of more conspicuous heterochromatic blocks at pericentromeric positions was reported in P. plectrodon (Nirchio et al., 2004b).

The heterochromatin in T. nattereri is observed in centromeric regions in most chromosome pairs. The heterochromatic blocks are more conspicuous in the centromeric region of the first and second chromosome pairs (metacentric). Such distribution pattern and amount of heterochromatin is similar to that reported in T. maculosa (Nirchio et al., 2004a). On the other hand, the cytogenetic data described for Thalassophryne differ from the pattern observed in the genus Porichthys (Brum et al., 2001; Nirchio et al., 2004b), i.e., large heterochromatic blocks restricted to some chromosome pairs, besides conspicuous pericentromeric heterochromatic segments in the first and second chromosome pairs. Such heterochromatin distribution has been referred to as vestiges of the Robertsonian fusions originating the two largest metacentric pairs in the karyotype (Brum et al., 2001).

The Ag-NORs in the karyotype of T. nattereri are single and located in telomeric regions of pair 19, subtelocentric. This result agrees with the pattern reported in several toadfish species (Palazón et al., 2003; Nirchio et al., 2004a,b; Merlo et al., 2007), thus suggesting that single NORs at the telomeric position should be regarded as a symplesiomorphic feature of Batrachoididae. The localization of ribosomal sites in distinct chromosome pairs could validate these regions as potential tools for cytotaxonomic purposes. However, the difficulty in the precise identification of the submetacentric, subtelocentric and acrocentric chromosomal types in the species analyzed, hinder the utilization of Ag-NORs as efficient chromosomal markers.

Both 5S and 18S rDNA sequences were mapped by fluorescence in situ hybridization in the species $H$. didactylus, revealing a non-syntenic chromosomal location, a common feature within several fish groups. Fluorescence in situ hybridization analyses in the same species using telomeric and (GATA)n probes failed to locate ectopic telomeric sites, while the GATA repeats were detected at the interstitial position on a single chromosome pair (Merlo et al., 2007). The absence of internal telomere-like sequences could be related either to the exclusion of these sites during fusion events or to the long time period since the numerical reduction in relation to the primitive teleostean karyotype $(2 n=48$ to $2 n=44-46)$ took place in Batrachoididae.

As reinforced by the present study, the karyotypic diversification in Thalassophryne and other members of this family can be associated with biological features of toadfishes. By presenting a sedentary behavior and a short larval stage, this fish group would be susceptible to a deep population structure, favorable to the fixation of chromosomal rearrangements.

Indeed, phylogenetic analyses based on mitochondrial DNA sequences corroborate that some genera, such as Opsanus, have undergone a fast evolutionary divergence. In this group of species, and probably in Thalassophryne as well, biogeographic barriers and envi- 
ronmental changes during the glacial periods support the hypothesis of allopatric speciation driven by vicarious events (Freshwater et al., 2000).

Although underrepresented, the available cytogenetic data in the family Batrachoididae suggest a potential field for taxonomic investigations in this group. In view of the few cytogenetic reports in species from the South Atlantic, further studies in a larger number of species are required, especially those focusing on chromosomal measurements and techniques of qualitative heterochromatin analysis, in order to provide a better understanding of the patterns related to the karyotype diversification in toadfishes.

\section{ACKNOWLEDGMENTS}

Research supported by Coordenação de Aperfeiçoamento de Pessoal Docente do Ensino Superior (CAPES), Conselho Nacional de Desenvolvimento Científico e Tecnológico (CNPq), and Universidade Federal do Rio Grande do Norte.

\section{REFERENCES}

Bertollo LAC, Takahashi CS and Moreira-Filho O (1978). Cytotaxonomic considerations on Hoplias lacerdae (Pisces, Erythrinidae). Rev. Bras. Genet. 1: 103-120.

Bertollo LA, Oliveira C, Molina WF, Margarido VP, et al. (2004). Chromosome evolution in the erythrinid fish, Erythrinus erythrinus (Teleostei: Characiformes). Heredity 93: 228-233.

Brum MJI (1996). Cytogenetic studies of Brazilian marine fish. Braz. J. Genet. 19: 421-427.

Brum MJI and Galetti PM Jr (1997). Teleostei ground plan karyotype. J. Comp. Biol. 2: 91-102.

Brum MJI, Affonso PRAM, Mota LCG, Pauls E, et al. (2001). Cytogenetic characterization of Porichtys porosissimus (Valenciennes, 1857) (Batrachoididae, Batrachoidiformes) from the Rio de Janeiro coast, Brazil. Chrom. Sci. 5: 15-18.

Cervigón F (1991). Los Peces Marinos de Venezuela. 2nd edn. Fundación Científica Los Roques, Caracas.

Chagas RB, Lopes PRD and Oliveira-Silva JT (2004). Cabuçu Notes about the feeding of Thalassophryne sp. (Actinopterygii: Batrachoididae) in Cabuçu Beach (Saubara, Baía de Todos os Santos, Bahia) [Notas sobre alimentação de Thalassophryne sp. (Actinopterygii: Batrachoididae) na praia de Cabuçu (Saubara, Baía de Todos os Santos, Bahia)]. Rev. Biocienc. 10: 231-234.

Chen WJ, Bonillo C and Lecointre G (2003). Repeatability of clades as a criterion of reliability: a case study for molecular phylogeny of Acanthomorpha (Teleostei) with larger number of taxa. Mol. Phylogenet. Evol. 26: 262-288.

Collette BB (1978). Batrachoididae. In: FAO Species Identification Sheets for Fishery Purposes. West Central Atlantic (Fishing Area 31) (Fischer W, ed.). Food and Agriculture Organization of the United Nations (FAO), Rome.

Diniz D and Xavier PM (2006). Easy Idio. Available at [http://geocities.yahoo.com.br/easyidio/]. Accessed April 22, 2009.

Facó PE, Bezerra GP, Barbosa PS, Martins AM, et al. (2005). Epidemiology of the injuries caused by Thalassophryne nattereri (niquim) in Ceará State (1992-2002). Rev. Soc. Bras. Med. Trop. 38: 479-482.

Floeter SR, Rocha LA, Robertson DR, Joyeux JC, et al. (2007). Atlantic reef fish biogeography and evolution. J. Biogeogr. 35: 22-47.

Freshwater DW, Khyn-Hansen C, Sarver SK and Walsh PJ (2000). Phylogeny of Opsanus spp. (Batrachoididae) inferred from multiple mitochondrial-DNA sequences. Mar. Biol. 136: 961-968.

Gold JR, Li YC, Shipley NS and Powers PK (1990). Improved methods for working with fish chromosomes with a review of metaphase chromosome banding. J. Fish Biol. 37: 563-575.

Greenfield DW (2006). Two new toadfish genera (Teleostei: Batrachoididae). Proc. Calif. Acad. Sci. 57: 945-954.

Haddad V Jr, Pardal PPO, Cardoso JLC and Martins IA (2003). The venomous toadfish Thalassophryne nattereri (niquim or miquim): report of 43 injuries provoked in fishermen of Salinópolis (Pará State) and Aracaju (Sergipe State). Rev. Inst. Med. Trop. São Paulo 45: 221-223.

Howell WM and Black DA (1980). Controlled silver-staining of nucleolus organizer regions with a protective colloidal developer: a 1-step method. Experientia 36: 1014-1015.

Lee MR and Elder FF (1980). Yeast stimulation of bone marrow mitosis for cytogenetic investigations. Cytogenet. Cell Genet. 26: 36-40. 
Levan A, Fredga K and Sandberg AA (1964). Nomenclature for centromeric position on chromosomes. Hereditas 52: 201-220.

Lopes-Ferreira M, Moura-da-Silva AM, Mota I and Takehara HA (2000). Neutralization of Thalassophryne nattereri (niquim) fish venom by an experimental antivenom. Toxicon 38: 1149-1156.

Lopes-Ferreira M, Emim JA, Oliveira V, Puzer L, et al. (2004). Kininogenase activity of Thalassophryne nattereri fish venom. Biochem. Pharmacol. 68: 2151-2157.

Menezes NA and Buckup PA (2003). Catálogo dos Peixes Marinhos e de Água Doce do Brasil. 2nd edn. Museu de Zoologia, Universidade de São Paulo, São Paulo.

Merlo A, Cross I, Palazon JL, Sarasquete C, et al. (2007). Chromosomal mapping of the major and minor ribosomal genes, (GATA)n and (TTAGGG)n by one-color and double-color FISH in the toadfish Halobatrachus didactylus (Teleostei: Batrachoididae). Genetica 131: 195-200.

Miya M, Takeshima H, Endo H, Ishiguro NB, et al. (2003). Major patterns of higher teleostean phylogenies: a new perspective based on 100 complete mitochondrial DNA sequences. Mol. Phylogenet. Evol. 26: 121-138.

Molina WF (2006). Chromosome Changes and Stasis in Marine Fish Groups. In: Fish Cytogenetics (Pisano E, OzoufCostaz C, Foresti F and Kapoor BG, eds.). Science Publisher, Enfield, 69-110.

Nelson JS (2006). Fishes of the World. 4th edn. John Wiley \& Sons, New York.

Nirchio M, Turner BJ, Pérez JE, Gaviria JI, et al. (2002). Karyotypes of three species of toadfish (Batrachoididae: Teleostei) from Venezuela. Sci. Mar. 66: 1-4.

Nirchio M, Fenocchio AS, Swarça AC, Dias AL, et al. (2004a). Cytogenetic characterization of Thalassophryne maculosa Günther, 1861 (Pisces: Batrachoididae) from Margarita Island, Venezuela. Caribb. J. Sci. 40: 218-222.

Nirchio M, Fenocchio AS, Swarça AC and Pérez JE (2004b). Karyology of the toadfish Porichthys plectrodon (Jordan and Gilbert, 1882) (Batrachoididae) from Margarita Island, Venezuela. Mar. Biol. 156: 161-165.

Palazón JL, Nirchio M and Sarasquete C (2003). Conventional karyotype and nucleolar organizer regions of the toadfish Halobachus didactylus (Schneider, 1801) (Pisces: Batrachoididae). Sci. Mar. 67: 445-449.

Randall JE (1983). Caribbean Reef Fishes. 2nd edn. T.F.H. Publications, Hong Kong.

Rocha LA, Bass AL, Robertson DR and Bowen BW (2002). Adult habitat preferences, larval dispersal, and the comparative phylogeography of three Atlantic surgeonfishes (Teleostei: Acanthuridae). Mol. Ecol. 11: 243-252.

Smith WL and Wheeler WC (2004). Polyphyly of the mail-cheeked fishes (Teleostei: Scorpaeniformes): evidence from mitochondrial and nuclear sequence data. Mol. Phylogenet. Evol. 32: 627-646.

Smith WL and Wheeler WC (2006). Venom evolution widespread in fishes: a phylogenetic road map for the bioprospecting of piscine venoms. J. Hered. 97: 206-217.

Stiassny MLJ, Wiley EO, Johnson GD and Carvalho MR (2004). Gnathostome Fishes. In: Assembling the Tree of Life (Cracraft J and Donoghue MJ, eds.). Oxford University Press, Oxford, 410-429.

Sumner AT (1972). A simple technique for demonstrating centromeric heterochromatin. Exp. Cell Res. 75: 304-306. 